\title{
DNA and Protein Synthesis in Developing Rat Pancreas
}

\author{
STEVEN L. WERLIN, DOUGLAS G. COLTON, SUCHART VIROJANAVAT, AND \\ EVANGELINE REYNOLDS \\ Department of Pediatrics, Division of Gastroenterology, The Medical College of Wisconsin and Children's \\ Hospital of Wisconsin, Milwaukee, Wisconsin 53201
}

\begin{abstract}
To define developmental patterns, we determined the rate of protein and DNA synthesis in rat pancreas at birth, 1, 2, 3, 7, 10, 14, 21, 28 days, 2 months, 3 months, and in adults. Fragments of freshly minced pancreas were incubated with $\left[{ }^{3} \mathrm{H}\right]$-thymidine and $\left[{ }^{14} \mathrm{C}\right]$-leucine and the DNA and protein synthesis rates were measured. We found that 1) DNA content was lowest at birth, rose through day 3 , plateaued at about $8 \mathrm{mg} / \mathrm{g}$ wet weight through day 14 , then slowly decreased to the adult value of about $5 \mathrm{mg} / \mathrm{g}$ at 2 months; 2) protein content, although high at birth, decreased rapidly to a value of $80 \mathrm{mg} / \mathrm{g}$ at day 3 and slowly rose to the adult value of $160 \mathrm{mg} / \mathrm{g} ; 3$ ) protein synthesis, low at birth, rapidly increased to about five times the adult value by day 3 , and remained elevated for the 1st month; 4) DNA synthesis was 15 times the adult rate at birth, increased to 30 times at 3 days of age, then declined slowly in an exponential fashion to the adult value. We conclude that the pancreas at birth is poised biosynthetically to undergo a rapid hyperplastic and hypertrophic response, and this process reaches a maximal rate at about 3 days of age. (Pediatr Res 22: 34-38, 1987)
\end{abstract}

\section{Abbreviations}

MEM, minimum essential medium

BSA, bovine serum albumin

SA, specific activity

PCA, perchloric acid

CCK, cholecystokinin

Numerous studies have defined the structural and functional development of rodent exocrine pancreas. Similarly, a number of studies has evaluated the effects of various agents thought to be trophic for the exocrine pancreas on DNA and protein content of the developing pancreas. Previous studies, however, have evaluated total DNA and protein content, but not actual rates of synthesis of DNA and protein at various ages (1-5). Since cellular content of biomolecules reflects the opposing actions of synthesis and degradation, the true effects of any agent tested may be masked when total organ content is measured. In addition, increases in DNA synthesis in the stomach and small intestine can be observed before an increase in DNA content itself (6). A further difficulty is that technically it is extremely difficult to remove the entire pancreas from neonatal rats. Accordingly, we have evaluated DNA and protein synthesis in rat pancreas of

Received October 21, 1986; accepted February 2, 1987.

Reprint requests Steven L. Werlin, M.D., Children's Hospital of Wisconsin, 1700 West Wisconsin Avenue, P.O. Box 1997, Milwaukee, WI 53201.

Supported by NICHHD Grant HD18433. various ages and compared synthetic rates to those found in the adult animal. Not surprisingly, the synthesis rates of both were found to be considerably higher in the immature animal than in the mature animal.

\section{MATERIALS AND METHODS}

Sprague Dawley rats obtained from King Laboratories, Madison, WI were used for all studies and were kept under controlled light and temperature conditions. After birth, the rats were not disturbed except for the addition of food and water. Pups were sacrificed at the stated ages $\pm 2 h$ for ages up to $72 h$, and \pm 1 day for ages 1 to 4 wk. Adult animals (males only) were 4-6 months old. The date of birth was designated as day 0 . Before weaning, rats were not fasted; after weaning (day 21), rats were fasted overnight before sacrifice, but allowed free access to water.

Eagle's MEM was from GIBCO, Grand Island, NY. Biorad reagent for protein assay was from Biorad, Richmond, CA. Calf thymus DNA and BSA were from Sigma, St. Louis, MO. Riaflour scintillation fluid was from Amersham, Chicago, IL. [Methyl$\left.{ }^{3} \mathrm{H}\right]$-thymidine (SA approximately $5 \mathrm{Ci} / \mathrm{mmol}$ ) and $\mathrm{L}-\left[{ }^{14} \mathrm{C}(\mathrm{U})\right]-$ leucine (SA $>300 \mathrm{mCi} / \mathrm{mmol}$ ) were from Amersham Corporation, Arlington Heights, IL.

\section{MEASUREMENT OF DNA AND PROTEIN SYNTHESIS}

After sacrifice by cervical dislocation, the pancreases were rapidly removed and placed in ice-cold MEM. Connective tissue and lymph glands were dissected. The tissue was minced into 1mm cubes and the medium was replaced by fresh MEM (containing $1 \mathrm{mM}$ leucine) so that the tissue concentration was 50 $\mathrm{mg} / \mathrm{ml}$. The tissue suspension was mixed by pipetting up and down several times and aliquots $(1.6 \mathrm{ml})$ were transferred to 25 $\mathrm{ml}$ polycarbonate flasks. From newborn to 7 days of age, one litter provided enough tissue for one flask. For experiments with rats 10 days of age or older, duplicate flasks were used.

The tissue suspension was gassed with $95 \% \mathrm{O}_{2} / 5 \% \mathrm{CO}_{2}$ and at zero time, $0.2 \mathrm{ml}$ each of $\left[{ }^{3} \mathrm{H}\right]$-thymidine $(2 \mu \mathrm{Ci} / \mathrm{ml})$ and $\left[{ }^{14} \mathrm{C}\right]$ -leucine $(2 \mu \mathrm{Ci} / \mathrm{ml})$ were added to each flask for a total volume of $2.0 \mathrm{ml}$ and placed in a shaking Dubnoff water bath at $37^{\circ} \mathrm{C}$, $100 \mathrm{cpm}$. After incubation for 30 min under $95 \% \mathrm{O}_{2} / 5 \% \mathrm{CO}_{2}$, the reaction was stopped with $2 \mathrm{ml}$ ice-cold $10 \%$ PCA containing $1 \mathrm{mM}$ unlabeled thymidine, and the flask placed on ice. The samples were homogenized at $0^{\circ} \mathrm{C}$ and centrifuged at $5000 \times g$ for $10 \mathrm{~min}$ at $4^{\circ} \mathrm{C}$. The precipitate was washed twice with $2 \mathrm{ml}$ cold 0.2 N PCA.

RNA was hydrolyzed by adding $2.0 \mathrm{ml}$ of $0.3 \mathrm{~N} \mathrm{KOH}$ and heating at $37^{\circ} \mathrm{C}$ for $60 \mathrm{~min}$. The tubes were placed on ice and $2.0 \mathrm{ml}$ of ice-cold $0.7 \mathrm{~N}$ PCA were added to reprecipitate DNA and protein. The tubes were centrifuged $\left(5000 \times \mathrm{g} 10 \mathrm{~min}\right.$ at $4^{\circ}$ C) and the pellets washed twice with $3 \mathrm{ml}$ of $0.2 \mathrm{~N}$ cold PCA. The DNA was extracted from the pellet in $3.0 \mathrm{ml}$ of $1.6 \mathrm{~N} \mathrm{PCA}$ 
and hydrolyzed by incubation at $70^{\circ} \mathrm{C}$ for $15 \mathrm{~min}$. The samples were centrifuged and the supernatants containing DNA were saved. The step was repeated and the two supernatants pooled. The amount of radioactivity $\left({ }^{3} \mathrm{H}\right)$ and the amount of deoxyribose in this supernatant was determined, respectively, by scintillation counting and the method of Burton (7) as modified by Giles and Myers (8).

In preliminary experiments (data not shown) we found that DNA and protein synthetic rates were linear up to $60 \mathrm{~min}$ of incubation, so a time of $30 \mathrm{~min}$ was chosen for the studies. We found that one 15 -min treatment with $1.6 \mathrm{~N}$ PCA released $88 \%$ and two treatments released $99 \%$ of the DNA in soluble form. Two treatments were used in all studies. Synthetic rates were independent of the amount of tissue up to $80 \mathrm{mg}$ per flask, therefore, we kept the amount of tissue at $60-80 \mathrm{mg}$ per flask.

The protein in the pellet was dissolved in $2.5 \mathrm{ml}$ of $0.3 \mathrm{~N}$ $\mathrm{KOH}$ by heating at $70^{\circ} \mathrm{C}$ for $5 \mathrm{~min}$ with stirring. The amount of radioactivity $\left({ }^{14} \mathrm{C}\right)$ and the amount of protein in this solution was determined, respectively, by scintillation counting and the dye-binding method of Bradford (9) using the Biorad reagents. The DNA and protein tissue contents were expressed as $\mathrm{mg}$ of DNA or protein per $g$ tissue. The protein content was divided by DNA content to obtain the protein/DNA ratio.

Samples were counted in a Packard Tri-Carb scintillation counter. Data were expressed as cpm $\left({ }^{3} \mathrm{H}\right)$ incorporated per mg DNA per $30 \mathrm{~min}$ or $\mathrm{cpm}\left({ }^{14} \mathrm{C}\right)$ incorporated per $\mathrm{mg}$ protein per $30 \mathrm{~min}$. The data were normalized by dividing each value by the mean value found in adults for DNA or protein synthesis.

Each experiment was performed three to five times at each age studied. Different litters were used for each point at each age. Statistical analysis was done using a linear contrast technique within an analysis of variance (10).

\section{RESULTS}

The DNA content (mg/g wet weight) at birth was significantly lower than all but the observation at 2 months $(p<0.01)$ (Fig. 1). There was a significant increase from newborn through $72 \mathrm{~h}$ $(p<0.001)$ followed by a leveling off through day 14 . This was followed by a significant decrease from day 14 through 2 months $(p<0.001)$ but no change from 2 months to adult.

The protein content $(\mathrm{mg} / \mathrm{g}$ wet weight) decreased significantly from birth to age $72 \mathrm{~h}(p<0.001)$ (Fig. 2). This was followed by a significant increase from 7 days through 28 days $(p<0.001)$, a fall at age 2 months, and a rise to a maximum value in the adult. The adult value was higher than the newborn $(p<0.05)$ and thus it is the highest of all values $(p<0.01)$.

The protein/DNA ratio in the pancreas decreased from birth to a low value at $48 \mathrm{~h}(p<0.001)$ since DNA content was increasing at the same time that protein content was decreasing (Fig. 3). There was no significant change from $48 \mathrm{~h}$ to 14 days, but there was a significant increase from 14 days through adult $(p<0.001)$ and from 21 days through adult $(p<0.001)$.

At birth and for the first $24 \mathrm{~h}$, protein synthesis was low and not different from the adult value (Fig. 4). From $48 \mathrm{~h}$ to 3 months, the rate was significantly higher than baseline $(p<$ 0.01 ), although there was no difference among the 48-h through day 28 values. This was followed by a significant decline from day 28 to the adult value $(p<0.01)$.

At birth the DNA synthetic rate was 15 times the rate found in adult pancreas (Fig. 5). The 2- and 3-day values were significantly elevated $(p<0.01)$ at $23-30$ times the adult value. However, the rate fell thereafter, as the 7-through 14-day values were not significantly different from the newborn/1-day values. There was a significant decrease from day 14 to adult $(p<$ 0.001 ), but it was not possible to distinguish where the decrease began (i.e. 7,10 , or 14 days).

\section{DISCUSSION}

The newborn pancreas is an excellent example of an organ which lacks many functions of adult tissue, despite appearing well developed anatomically (11). In the newborn rat pancreas, abundant zymogen granules can be seen and the organ appears poised to secrete (12). Despite anatomic maturity, the acinar cells respond neither to muscarinic nor to hormonal secretagogues until $24 \mathrm{~h}$ of age (13-15). This appears due to a deficiency of both muscarinic and CCK receptors (16-18). The postreceptor $\mathrm{Ca}^{++}$transducing machinery appears to be functional at birth (13-15).

We found that DNA content per $g$ of tissue generally increased with developmental age. After an initial decrease in protein content, presumably because of rapid depletion of zymogen granules, protein content also increased. The increase in DNA

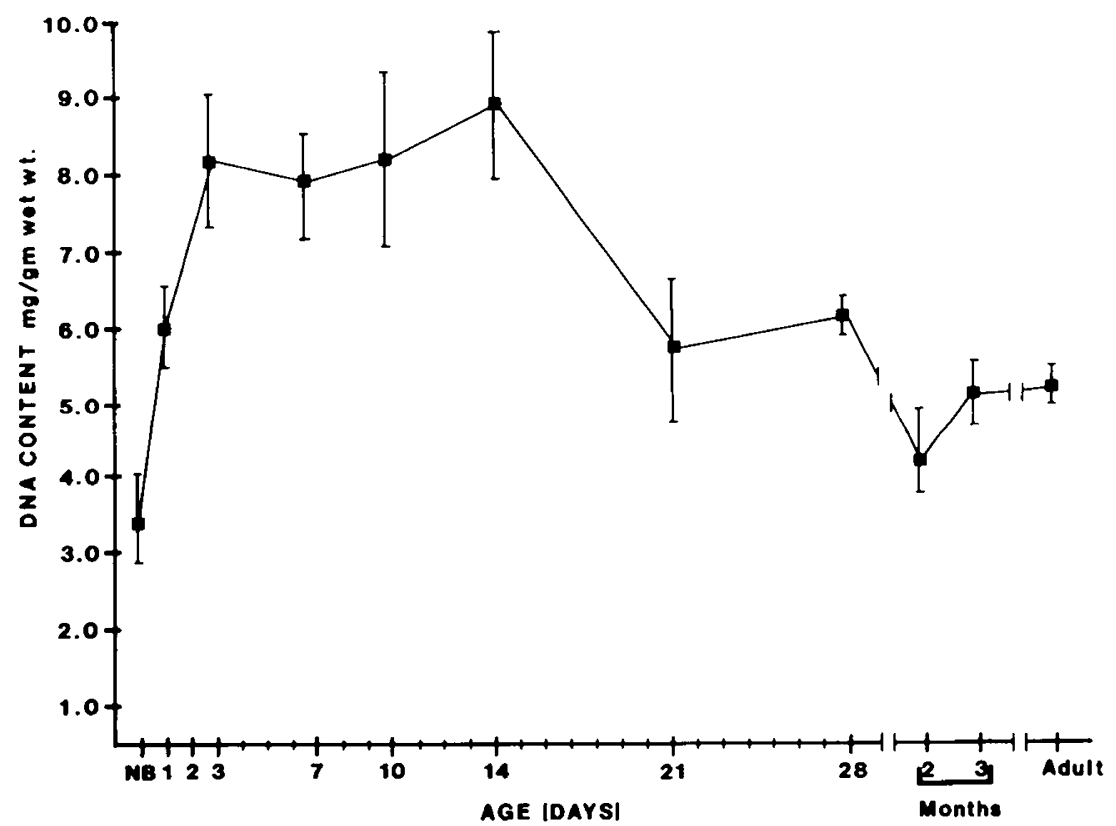

Fig. 1. DNA content of developing rat pancreas. Each value is the mean \pm SEM of three to five experiments. The highest values were from day 3 through day $14(p<0.001)$ 


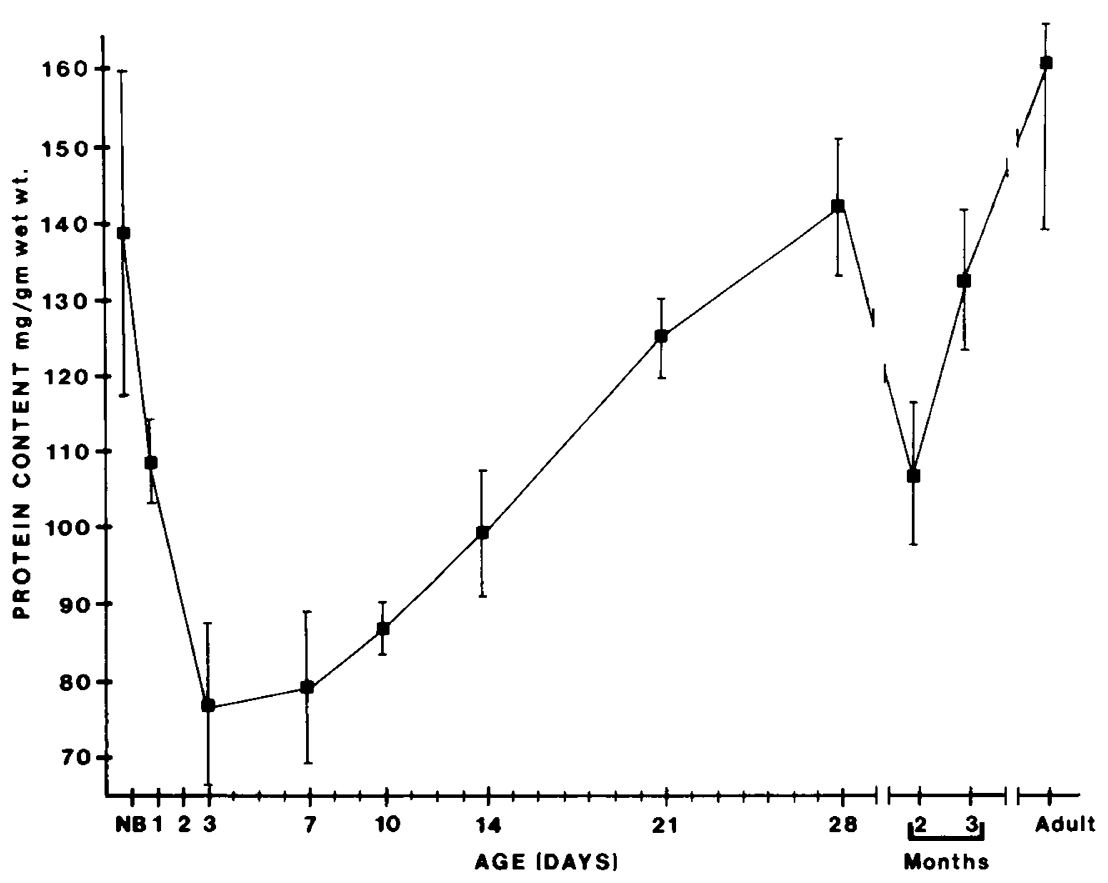

Fig. 2. Protein content of developing rat pancreas. Each value is the mean $\pm \mathrm{SEM}$ of three to five experiments. The adult value is the highest ( $p$ $<0.01)$ and the lowest levels are at day 3 and day $7(p<0.001)$.

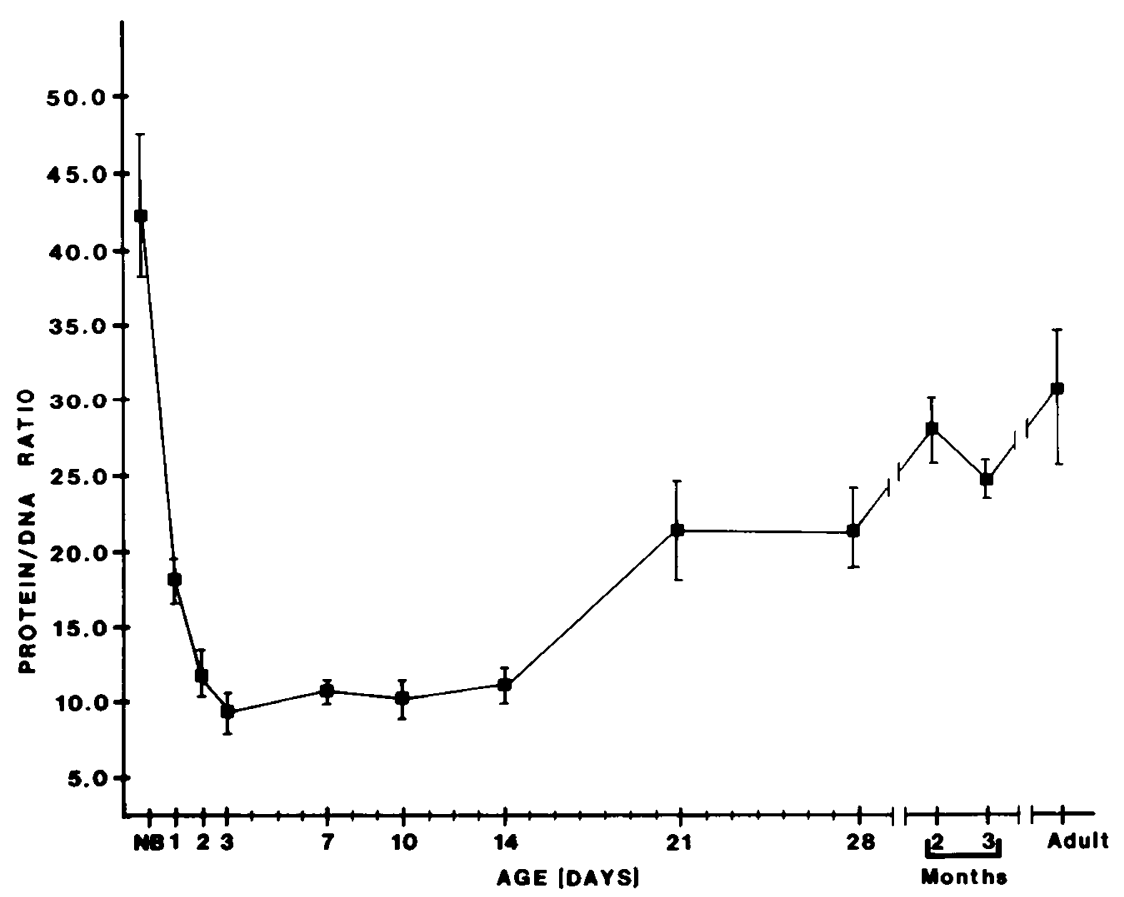

Fig. 3. The ratio of protein to DNA in developing rat pancreas. Each value is the mean \pm SEM of three to five experiments. A plateau minimum was observed from day 2 through day $14(p<0.001)$.

content at 1-2 days of age may be partly due to zymogen granule discharge. Both DNA and protein synthetic rates remain elevated (compared to adult rates) for at least 2 months after birth.

Besides gaining functional activity, the pancreas undergoes both hyperplastic and hypertrophic responses, as assessed by increases in organ weight and DNA, RNA, and protein content. Although the pancreas is composed of both exocrine and endocrine tissue, the former represents by far the greatest proportion of tissue. Thus, when measuring DNA, RNA, or protein content or their respective rates of synthesis the presumption is made that changes primarily represent alterations in exocrine tissue.
This is supported by the observation that when rats are given $\left[{ }^{3} \mathrm{H}\right]$-thymidine in vivo and their pancreases subsequently processed for autoradiography, the isotope is found predominantly located over acinar cells. This is even true after caerulein treatment in which the pancreas undergoes a hyperplastic response as occurs in the developing pancreas (19). Increasing DNA and protein content can occur either by an increase in synthesis, by a decrease in breakdown, or both. In this study, we have demonstrated high rates of synthesis of both DNA and protein in pancreases of young rats.

Pollack et al. (20) reported that in isolated acini prepared from 


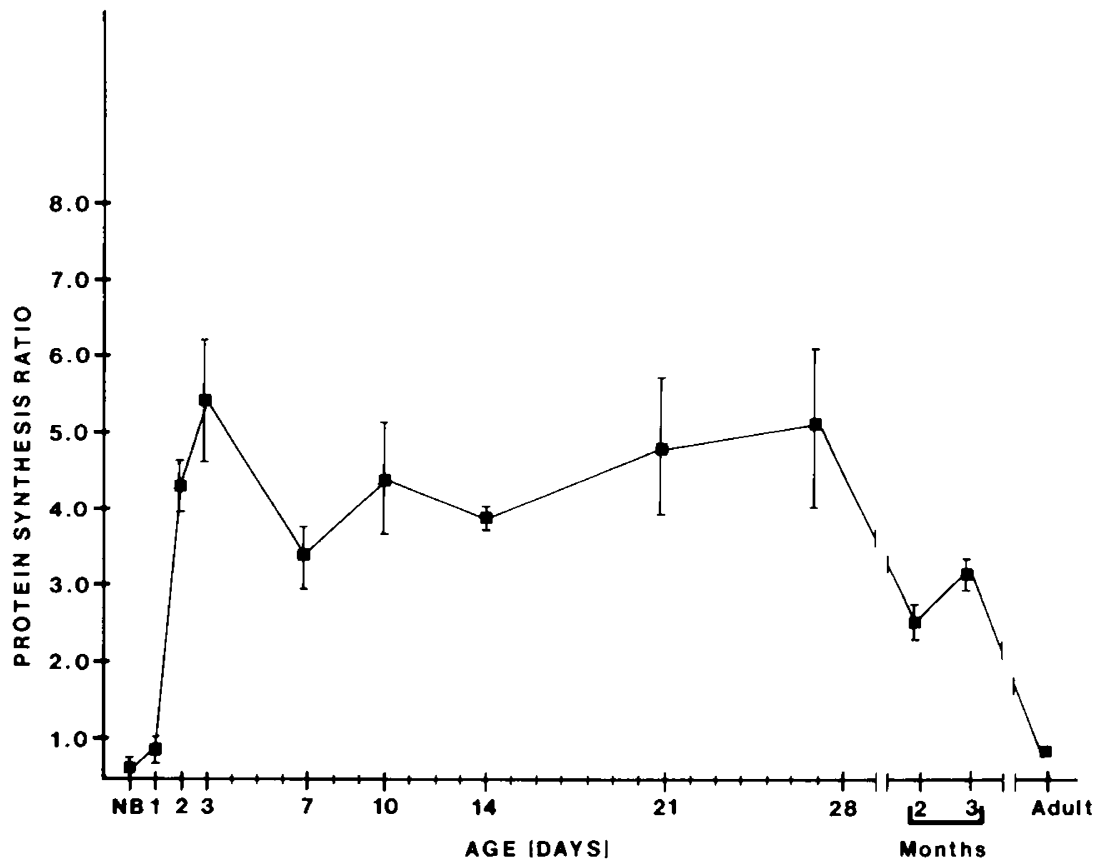

Fig. 4. The protein synthesis ratio in developing rat pancreas. Each value is the mean \pm SEM of three to five experiments. The protein synthesis rate in $\mathrm{cpm}\left[{ }^{14} \mathrm{C}\right]$-leucine incorporated per mg protein at each age was divided by the mean adult rate to obtain the protein synthesis ratio.

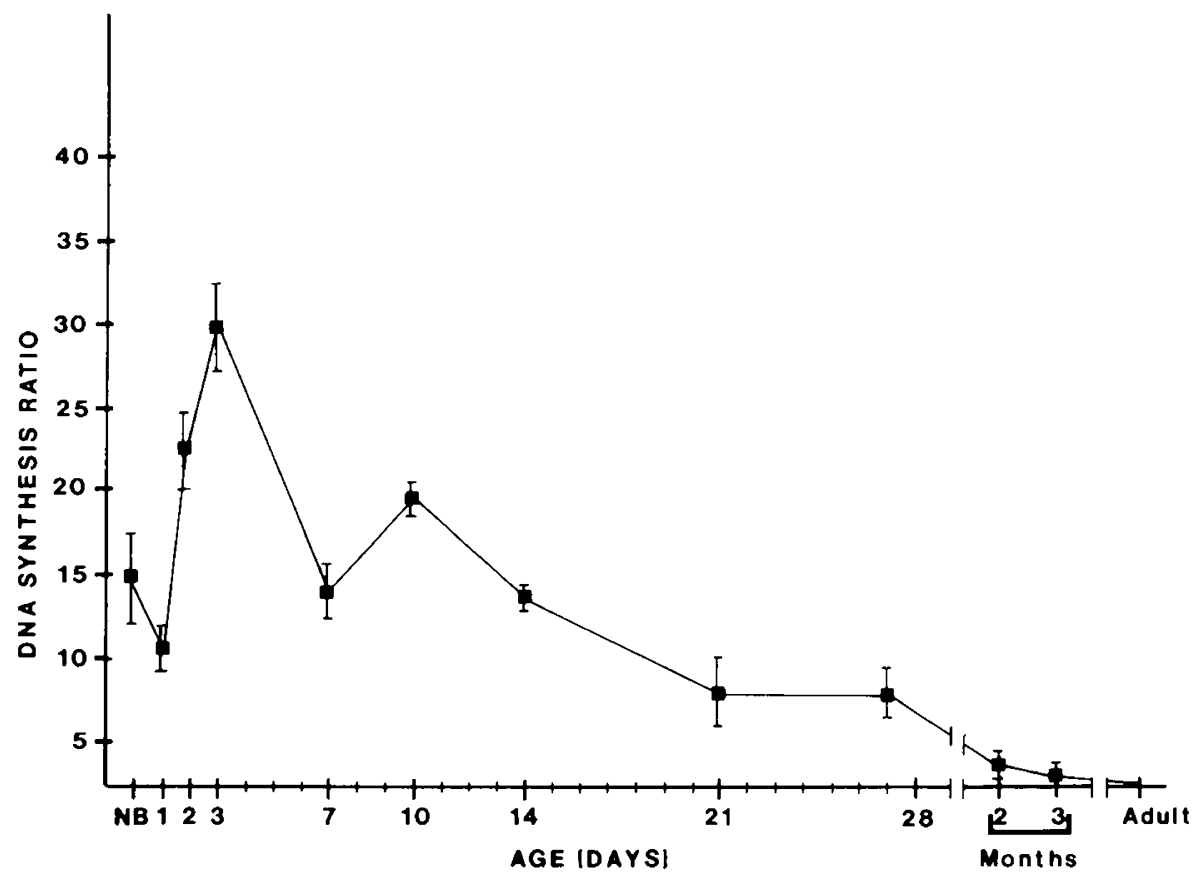

Fig. 5. The DNA synthesis ratio in developing rat pancreas. Each value is the mean \pm SEM of three to five experiments. The DNA synthesis ratio in cpm $\left[{ }^{3} \mathrm{H}\right]$-thymidine incorporated per mg DNA at each age was divided by the mean adult rate to obtain the DNA synthesis ratio.

8-day-old rats, the rate of incorporation of $\left[{ }^{3} \mathrm{H}\right]$-leucine was about one-fifth the adult rate. Since the pancreas is growing rapidly at this age, we believe this suggests that their isolated acini preparation is abnormal in comparison to acini in undigested tissue, and therefore our data showing a higher rate of protein (and DNA) synthesis at these younger ages is more consistent with the biology of this organ.

Before weaning, we did not fast the rats overnight, but after weaning (i.e. at 21 days) we did. In preliminary experiments, we found that protein synthesis was higher in fed adult rats than in fasted rats, however, the animal-to-animal variability was consid- erable, perhaps because fed animals actually feed according to their own individual schedules during the night, and their state of satiety and degree of synchronization at the time of sacrifice (about $1000 \mathrm{~h}$ ) is unknown. We therefore chose to use fasted animals where practicable.

We also found that overnight fasting of younger rats led to unacceptably high morbidity and mortality. We therefore did not fast the rats until after weaning, 21 days of age. We believe that within the context of this study that this issue is not significant. Although the group at 21 days (weanlings) was fed, and the group at 28 days (postweaning) was fasted, both the temporal 
DNA and protein synthetic rate curves were "smooth" at this transition point in feeding status $(p>0.5)$.

We incubated minced tissue with tracer amounts of $\left[{ }^{3} \mathrm{H}\right]-$ thymidine as described by Johnson and Guthrie (21). Morisset et al. (22) used larger, unminced tissue fragments which might be expected to present greater problems in maintaining tissue oxygenation than minced tissue. Nevertheless, they found that free labeled thymidine pools were not affected by treatment with caerulein, implying that assaying this pool is unnecessary. At the end of the incubation, we stopped the incorporation by adding cold PCA containing unlabeled thymidine to ensure that any label found in the DNA fraction was covalently incorporated.

Morisset and Webster (23) found that incorporation of $\left[{ }^{14} \mathrm{C}\right]-$ phenylalanine at a concentration of $48 \mu \mathrm{M}$ into protein was linear for at least $120 \mathrm{~min}$ in adult pancreas and the rate of incorporation was not dependent on phenylalanine pool size. In contrast Bauduin et al. $(24,25)$ found that while incorporation of $\mathrm{L}-\left[4,5-{ }^{3} \mathrm{H}\right]$-leucine in vitro into rat pancreas was linear for less than $20 \mathrm{~min}$ at a concentration of $26 \mu \mathrm{M}$ leucine, it was linear for $2 \mathrm{~h}$ at a concentration of $0.8 \mathrm{mM}$. We incubated our minces in the presence of $1 \mathrm{mM}$ leucine. Thus, the pool size of $\left[{ }^{3} \mathrm{H}\right]-$ leucine is probably not the determining factor of the changes in rates of protein synthesis that we observed.

Since the newborn rat pancreas has many zymogen granules, a characteristic of fasted adult pancreas $(12,26,27)$, it is not surprising that the protein content of the newborn pancreas is high. Teleologically, the pancreas at this age does not "need" high rates of protein synthesis. A large increase in protein synthesis does occur at $48 \mathrm{~h}$, at the time when we and others have shown both increased binding of CCK and responsiveness to CCK and carbachol (13-18). DNA synthesis, in contrast, already high at birth, reaches a maximum at $72 \mathrm{~h}$ of age, then slowly declines exponentially to adult levels. The high rate of DNA synthesis is necessary for the hyperplastic response of the organ.

Various agents such as CCK, bombesin, and epidermal growth factor influence growth in the adult pancreas (28-35). Undoubtedly, these agents act upon the immature pancreas as well, regulating DNA, RNA, and protein synthesis, and therefore growth in a coordinated manner. In this study, we have provided a framework by which the potential actions of these agents on these fundamental processes can be studied in the neonatal animal.

Acknowledgments. The authors thank Raymond G. Hoffman, $\mathrm{Ph} . \mathrm{D}$. for assistance in the statistical analysis of the data and Ms. Dawn Schlechta for typing the manuscript.

\section{REFERENCES}

1. Morisset J, Jolicoeur L, Genik P, Lord A 1981 Interaction of hydrocortisone and caerulein on pancreatic size and composition in the rat. Am $\mathbf{J}$ Physiol 241:G37-G42

2. Morriset J, Jolicoeur L 1980 Effect of hydrocortisone on pancreatic growth in rats. Am J Physiol 239:G85-G93

3. Brants F, Morrisset J 1976 Trophic effect of cholecystokin-pancreaozymin on pancreatic acinar cells from rats of different ages. Proc Soc Exp Biol Med 153:523-527

4. Werlin SL, Stefaniak J 1982 Effects of hydrocortisone and cholecystokinoctapeptide on neonatal rat pancreas. J Pediatr Gastroenterol Nutr 1:591595

5. Werlin SL, Stefaniak J 1983 Effects of cholecystokinin octapeptide and hydrocortisone on the development of the fetal rat pancreas. Biol Neonate 44:287294

6. Solomon TE 1986 Trophic effects of pentagastrin in gastrointestinal tract in fed and fasted rats. Gastroenterology 91:108-116
7. Burton K 1956 Diphenylamine reaction for estimation of DNA. Biochem J 62:315-322

8. Giles KW, Myers A 1965 Improved diphenylamine method for estimation of DNA. Nature 206:93

9. Bradford M $1976 \mathrm{~A}$ rapid and sensitive method for the quantitation of microgram quantities of protein utilizing the principle of protein-dye binding. Anal Biochem 72:248-255

10. Kirk RE 1982 Experimental Design: Procedures for the Behavioral Sciences. Brooks/Cole Publishing Co., Monterey, CA, p 90.

11. Lebenthal E, Lev R, Lee PC 1986 Prenatal and postnatal development of the human exocrine pancreas. In: Go VLW, Gardner JD, Brooks FP, Lebenthal E, DiMagno EP, Scheele GA (eds) The Exocrine Pancreas: Biology, Pathobiology, and Disease. Raven Press, New York, pp 33-43

12. Harb JM, Werlin SL, Taylor JJ, Stefaniak J 1982 Effects of cholecystokinin octapeptide and hydrocortisone on the exocrine pancreas of fed and fasted 24-hour-rats: an electron microscopic study. Exp Mol Pathol 37:92-100

13. Werlin SL, Grand RJ 1979 Development of secretory mechanisms in rat pancreas. Am J Physiol 236:E446-E450

14. Werlin SL, Stefaniak J 1982 Effects of hydrocortisone and cholecystokinin octapeptide on neonatal rat pancreas. J Pediatr Gastroenterol Nutr 1:591595

15. Werlin SL, Stefaniak J 1982 Maturation of secretory function in rat pancreas. Pediatr Res 16:123-125

16. Dumont Y, LaRose L, Morriset J, Poirer GG 1981 Parallel maturation of the pancreatic secretory response to cholinergic stimulation and the muscarinic receptor population. Br J Pharmacol 73:345-354

17. Werlin SL, Colton DG, Harb J, Reynolds E, Hoffman RG, Williams JA 1986 Ontogeny of secretory function and cholecystokinin binding capacity in immature rat pancreas. Gastroenterology 90:1687(abstr)

18. Leung YK, Lee PC, Lebenthal E 1986 Maturation of cholecystokinin receptors in pancreatic acini of rats. Am J Physiol 250:G594-G597

19. Solomon TE, Vanier M, Morrisset J 1983 Cell site and time course of DNA synthesis in pancreas after caerulein and secretin. Am J Physiol 245:G99G105

20. Pollack PF, Verbridge J, Thornburg W, Koldovsky O, Korc M 1986 Isolated pancreatic acini from suckling and weaning rats: changes in amino acid incorporation and carbachol-stimulated amylase secretion with age. Biol Neonate 49:344-350

21. Johnson LR, Guthrie P 1976 Effect of cholescystokinin and 16, 16-dimethyl prostaglandin $\mathrm{E}_{2}$ on RNA and DNA of gastric and duodenal mucosa. Gastroenterology 70:59-65

22. Morisset J, Chamberland S, Gilbert L, Lord A, Larose L 1982 Study of pancreatic DNA synthesis in vivo and in vitro following caerulein treatments in vivo. Biomed Res 3:151-158

23. Morisset JA, Webster PD 1972 Effects of fasting and feeding on protein synthesis by the rat pancreas. $\mathrm{J}$ Clin Invest $51: 1-8$

24. Bauduin H, Tondeur T, Van Sande J, Vincent D 1973 Secretion and protein metabolism in the rat pancreas in vitro. Biochim Biophys Acta 304:81-92

25. Bauduin H, Colin M, Dumont JE 1969 Energy sources for protein synthesis and enzymatic secretion in vitro. Biochim Biophys Acta 174:722-733.

26. Ermak TH, Rothman SS 1980 Large decrease in zymogen granule size in the postnatal rat pancreas. J Ultrastruct Res 70:242-256

27. Ermak TH, Rothman SS 1981 Zymogen granules of pancreas decrease in size in response to feeding. Cell Tissue Res 214:51-66

28. Solomon TE, Peterson H, Elashoff J, Grossman MI 1979 Effects of chemical messenger peptides on pancreatic growth in rats. In: Miyashi A (ed) Gut Peptides. Elsevier, New York, pp 213-219

29. Wood JG, Solomon TE 1983 Trophic effect of $\mathrm{Ca}^{++}$-dependent secretagogues on pancreas and gastrointestinal tract of rats. Gastroenterology 84:1354(abstr)

30. Lhoste E, Aprahamian M, Pousse A, Stock-Damage C 1985 Trophic effect of bombesin on the rat pancreas. Lack of inhibition by antrectomy or proglumide-treatment. In: Lewin MJM, Bonfils S (eds) Regulatory Peptides in Digestive, Nervous and Endocrine Systems. Elsevier, Amsterdam, pp 417 420

31. Morisset J, Benrezzak O 1984 Polyamines and pancreatic growth induced by caerulein. Life Sci 35:2471-2480

32. Johnson LR 1981 Effects of gastrointestinal hormones on pancreatic growth. Cancer 47:1640-1645

33. Ihse I, Arnesjo B, Lundquist I 1976 Effects on exocrine and endocrine rat pancreas of long-term administration of CCK-PZ (cholecystokinin-pancreozymin) or synthetic octapeptide. Scand J Gastroenterol 11:529-535

34. Solomon TE, Petersen H, Elashoff J, Grossman MI 1978 Interaction of caerulein and secretion on pancreatic size and composition in rat. Am J Physiol 235:E714-E719

35. Dembinski A, Gregory H, Konturek S, Polanski M 1982 Trophic action of epidermal growth factor on the pancreas and gastroduodenal mucosa in rats. J Physiol 325:35-42 